\title{
INVESTIGATION OF PHYSICAL ACTIVITY LEVEL IN COVID-19 PANDEMIC PERIOD OF AMATEUR AND PROFESSIONAL SOCCER PLAYERS
}

\author{
Mustafa Burak Cağdanlioğlu' ${ }^{1 \mathrm{i}}$, \\ Mürsel Biçer ${ }^{2 i}$, \\ Mehmet Vural ${ }^{3}$ \\ ${ }^{1}$ Gaziantep University, \\ Health Sciences Institute, \\ Turkey \\ 2Prof. Dr., \\ Gaziantep University, \\ Health Sciences Institute, \\ Turkey \\ ${ }^{3}$ Gaziantep University, \\ Faculty of Sport Sciences, \\ Turkey
}

\begin{abstract}
:
The aim of this study is to examine the physical activity levels of amateur and professional football players during the covid-19 pandemic period. For this purpose, 54 amateur female, 69 amateur male and 36 professional male football players participated in the study. The long version of the international physical activity questionnaire (IPAQ) was used to determine the physical activity levels of the participants. SPSS 22.0 (SPSS Inc., Chicago, Illinois, USA) program was used for statistical processing of the data. Values were presented as minimum, maximum, mean, standard deviation, and standard error. Significance level was accepted as $\mathrm{p}<0.05$. Kolmogorov-Smirnov test was used for normality test. One Way Anova and LSD tests were performed to analyze the differences between groups. As a result of the statistical analysis, a significant difference was found in the total MET scores of amateur women and amateur men for home-garden work $(p<0.05)$. A significant difference was found in the transportation section bicycle MET scores of the professional male and amateur female groups $(p<0.05)$. There was no significant difference between the MET scores of the age and sports age groups of the participants ( $p>0.05)$. As a result, it can be said that the physical activity levels of amateur women, amateur men and professional men groups are low.
\end{abstract}

Keywords: physical activity, pandemic, quarantine, soccer

${ }^{i}$ Correspondence: email mustafacoglu@hotmail.com $\underline{\text { mbicer@gantep.edu.tr }}$ 


\section{Introduction}

Football is one of the most popular sports in the world. Because football is a very entertaining game, it is highly sought after by most people around the world. It is also a game that fascinates millions of people. Every age group is very interested in football, from young to old. The most important factor to be successful in sports is to perform at a high level and to maintain this performance at a high level. Performance level in football is not only determined by physical characteristics. Performance in football is also determined by technical, tactical and mental characteristics. In order to maintain the performance in football throughout the season, training planning should be done correctly and effectively during the season along with the pre-season preparation period. Keeping the performance level high throughout the season provides significant gains in competitions. Having a good talent is not the only determining factor for performance in football. In addition to a good ability, basic motoric features and a high level of tactical ability are the main determining factors for performance in football $(1,2,15)$.

The high level of fitness of the athletes is closely related to their success. When we look at the successful athletes, it is seen that their form level is quite high. In order to maintain and increase the fitness levels of the athletes, training programs should be applied twice a week. Training programs should include strength, aerobic and anaerobic endurance, balance, speed, agility, agility and technical-tactical practices $(3,16,17)$.

According to this information, the importance of our research is to examine the physical activity levels of amateur and professional football players during the covid-19 pandemic period and to have information about the fitness of the athletes.

The aim of our study is to examine the physical activity levels of amateur and professional football players during the covid-19 pandemic period.

\section{Method}

In this study, the questionnaire method was used to determine the physical activity levels of amateur and professional football players during the covid-19 period. The questionnaire was prepared in the digital environment and amateur and professional football players were accessed in this way. The long version of the international physical activity questionnaire (IPAQ) was used to determine the physical activity level of amateur and professional football players. The universe of the research is amateur and professional football players who compete in football leagues. The sample consists of 54 female amateur football players, 69 male amateur football players and 36 male professional football players in the amateur and professional leagues in Turkey. SPSS 22.0 (SPSS Inc., Chicago, Illinois, USA) program was used for statistical processing of the data. Values were presented as minimum, maximum, mean, standard deviation, and standard error. Significance level was accepted as $p<0.05$. The Kolmogorov-Smirnov test was used to test for normality. One Way Anova and LSD tests were performed to analyze the differences between groups. 


\section{Results}

The data obtained from this study, which examined the physical activity levels of amateur and professional football players during the covid-19 pandemic period, are presented in tables in this section.

Table 1: Analysis of participants' total MET-minutes/week scores by athlete level

\begin{tabular}{|c|c|c|c|c|c|c|c|}
\hline & & Mean & Std. D. & Std. E. & $\mathrm{f}$ & $\mathrm{p}$ & Difference \\
\hline \multirow{3}{*}{$\begin{array}{l}\text { Work total } \\
\text { MET scores }\end{array}$} & Amateur woman a & 3237.40 & 2429.08 & 330.56 & \multirow{3}{*}{0.522} & \multirow{3}{*}{0.59} & \\
\hline & Amateur male b & 3616.38 & 2301.34 & 277.05 & & & \\
\hline & Professional male c & 3236.32 & 2189.31 & 364.89 & & & \\
\hline \multirow{3}{*}{$\begin{array}{l}\text { Transportation } \\
\text { total MET scores }\end{array}$} & Amateur woman a & 1062.78 & 848.04 & 115.40 & \multirow{3}{*}{0.787} & \multirow{3}{*}{0.45} & \\
\hline & Amateur male b & 993.78 & 994.10 & 119.68 & & & \\
\hline & Professional male c & 1232.79 & 913.89 & 152.32 & & & \\
\hline \multirow{3}{*}{$\begin{array}{l}\text { Home-gardening } \\
\text { total MET scores }\end{array}$} & Amateur woman a & 1954.49 & 1522.22 & 207.15 & \multirow{3}{*}{3.367} & \multirow{3}{*}{0.04} & \multirow{3}{*}{$a-b$} \\
\hline & Amateur male b & 1227.07 & 1517.08 & 182.64 & & & \\
\hline & Professional male c & 1613.33 & 1646.85 & 274.47 & & & \\
\hline \multirow{3}{*}{$\begin{array}{l}\text { Leisure total } \\
\text { MET scores }\end{array}$} & Amateur woman a & 2717.57 & 1952.36 & 265.68 & \multirow{3}{*}{0.057} & \multirow{3}{*}{0.945} & \\
\hline & Amateur male b & 2644.64 & 2256.97 & 271.71 & & & \\
\hline & Professional male c & 2786.08 & 1955.44 & 325.91 & & & \\
\hline
\end{tabular}

In Table 1, the analysis of the total MET-minutes/week scores of the participants according to the athlete's level is presented. One Way Anova and LSD test were used to compare total MET-minute/week scores according to athlete level. As a result of the analysis, no significant difference was found between the work total MET scores, transportation total MET scores, and leisure total MET scores of the amateur female, amateur male and professional male groups ( $\mathrm{p}>0.05)$. However, a significant difference was found in favor of amateur women in the analysis of home-gardening total MET scores of amateur women and amateur men groups $(\mathrm{p}<0.05)$.

Table 2: Analysis of the field-specific MET-minutes/week scores of the participants according to the athlete level

\begin{tabular}{|c|c|c|c|c|c|c|c|}
\hline & & Mean & Std. D. & Std. E. & $\mathrm{f}$ & $\mathrm{p}$ & Difference \\
\hline \multirow{3}{*}{$\begin{array}{l}\text { Work } \\
\text { walking } \\
\text { MET scores }\end{array}$} & Amateur woman a & 928.28 & 952.79 & 129.66 & \multirow{3}{*}{0.155} & \multirow{3}{*}{0.856} & \\
\hline & Amateur male b & 922.61 & 907.45 & 109.24 & & & \\
\hline & Professional male c & 831.42 & 738.14 & 123.02 & & & \\
\hline \multirow{3}{*}{$\begin{array}{l}\text { Work moderate } \\
\text { severity } \\
\text { MET scores }\end{array}$} & Amateur woman a & 979.26 & 919.52 & 125.13 & \multirow{3}{*}{0.139} & \multirow{3}{*}{0.870} & \\
\hline & Amateur male b & 950.14 & 859.61 & 103.48 & & & \\
\hline & Professional male c & 882.78 & 748.27 & 124.71 & & & \\
\hline \multirow{3}{*}{$\begin{array}{l}\text { Work high } \\
\text { severity } \\
\text { MET scores }\end{array}$} & Amateur woman a & 1371.11 & 1082.40 & 147.30 & \multirow{3}{*}{1.512} & \multirow{3}{*}{0.224} & \\
\hline & Amateur male b & 1743.62 & 1175.03 & 141.46 & & & \\
\hline & Professional male c & 1485.00 & 1452.75 & 242.12 & & & \\
\hline \multirow{3}{*}{$\begin{array}{l}\text { Transportation } \\
\text { bike } \\
\text { MET scores }\end{array}$} & Amateur woman a & 188.89 & 480.48 & 65.39 & \multirow{3}{*}{3.537} & \multirow{3}{*}{0.031} & \multirow{3}{*}{$c-a$} \\
\hline & Amateur male b & 296.52 & 717.34 & 86.36 & & & \\
\hline & Professional male c & 545.83 & 644.30 & 107.38 & & & \\
\hline Transportation & Amateur woman a & 873.89 & 740.83 & 100.81 & 1.248 & 0.290 & \\
\hline
\end{tabular}


Mustafa Burak Cağdanlioğlu, Mürsel Biçer, Mehmet Vural

INVESTIGATION OF PHYSICAL ACTIVITY LEVEL IN COVID-19 PANDEMIC

PERIOD OF AMATEUR AND PROFESSIONAL SOCCER PLAYERS

\begin{tabular}{|c|c|c|c|c|c|c|c|}
\hline \multirow{2}{*}{$\begin{array}{l}\text { walking } \\
\text { MET scores }\end{array}$} & Amateur male b & 697.25 & 670.75 & 80.75 & & & \\
\hline & Professional male c & 686.96 & 605.51 & 100.92 & & & \\
\hline \multirow{3}{*}{$\begin{array}{l}\text { Gardening } \\
\text { severe } \\
\text { MET scores }\end{array}$} & Amateur woman a & 451.71 & 684.90 & 93.20 & \multirow{3}{*}{1.265} & \multirow{3}{*}{0.285} & \\
\hline & Amateur male b & 425.65 & 710.48 & 85.53 & & & \\
\hline & Professional male c & 650.83 & 765.89 & 127.65 & & & \\
\hline \multirow{3}{*}{$\begin{array}{l}\text { Gardening } \\
\text { moderate } \\
\text { MET scores }\end{array}$} & Amateur woman a & 696.67 & 830.24 & 112.98 & \multirow{3}{*}{2.776} & \multirow{3}{*}{0.065} & \\
\hline & Amateur male b & 402.03 & 529.80 & 63.78 & & & \\
\hline & Professional male c & 520.00 & 724.37 & 120.73 & & & \\
\hline \multirow{3}{*}{$\begin{array}{l}\text { Housework } \\
\text { moderate severity } \\
\text { MET scores }\end{array}$} & Amateur woman a & 806.11 & 670.77 & 91.28 & \multirow{3}{*}{7.816} & \multirow{3}{*}{0.001} & \\
\hline & Amateur male b & 399.39 & 538.16 & 64.79 & & & \\
\hline & Professional male c & 442.50 & 574.88 & 95.81 & & & \\
\hline \multirow{3}{*}{$\begin{array}{l}\text { Leisure } \\
\text { walking } \\
\text { MET scores }\end{array}$} & Amateur woman a & 592.39 & 639.07 & 86.97 & \multirow{3}{*}{0.445} & \multirow{3}{*}{0.642} & \\
\hline & Amateur male b & 687.63 & 687.56 & 82.77 & & & \\
\hline & Professional male c & 589.42 & 532.34 & 88.72 & & & \\
\hline \multirow{3}{*}{$\begin{array}{l}\text { Leisure severe } \\
\text { MET scores }\end{array}$} & Amateur woman a & 1636.30 & 1519.01 & 206.71 & \multirow{3}{*}{0.087} & \multirow{3}{*}{0.917} & \\
\hline & Amateur male b & 1544.20 & 1506.00 & 181.30 & & & \\
\hline & Professional male c & 1515.56 & 1435.80 & 239.30 & & & \\
\hline \multirow{3}{*}{$\begin{array}{l}\text { Leisure moderate } \\
\text { intensity } \\
\text { MET scores }\end{array}$} & Amateur woman a & 488.89 & 630.01 & 85.73 & \multirow{3}{*}{1.460} & \multirow{3}{*}{0.235} & \\
\hline & Amateur male b & 438.53 & 708.25 & 85.89 & & & \\
\hline & Professional male c & 681.11 & 775.13 & 129.19 & & & \\
\hline
\end{tabular}

In Table 2, the analysis of the field-specific MET-minutes/week scores according to the athlete's level of the participants is presented. One Way Anova and LSD test were used to compare field-specific MET-minute/week scores according to athlete level. As a result of the analysis, no significant difference was found between the division of labor, transportation division (except bicycle), home-gardening division and leisure time division of amateur women, amateur men and professional men groups $(p>0.05)$. However, a significant difference was found between the transportation section bicycle MET scores of professional men and amateur women groups in favor of professional men $(\mathrm{p}<0.05)$.

\section{Discussion and Conclusion}

As a result of the international physical activity questionnaire applied in our study, the total MET-minute/week scores of the participants and the field-specific METminutes/week scores were compared according to the athlete's level. There was no significant difference between the total MET scores of work, total MET scores of transportation, and total MET scores of leisure time according to the athlete level of the participants. However, a significant difference was found between the home-garden total MET scores of amateur women and amateur men groups in favor of amateur women. When comparing the field-specific MET-minute/week scores of the participants according to the athlete's level, no significant difference was found between the work division MET scores, the transportation division walking MET score, the homegardening division MET scores and the leisure segment MET scores. However, a 
significant difference was found between the transportation section bicycle MET scores of professional men and amateur women groups in favor of professional men.

In 2019, Süsler conducted a thesis study on university students' physical activity levels and their desire for excessive food consumption. As a result of the study, it was found that male students' division of labor and physical activity levels were higher than females. In our study, however, no significant difference was found in the comparison of physical activity between the groups of amateur women, amateur men and professional men. The reason for this is thought to be due to the banning of sports competitions and the closed sports fields during the pandemic period. When we look at the other findings in the study of ornaments; It has been determined that sports management students are more active in the home-gardening department compared to the coaching and teaching department. In the comparison of home-garden work in our study, amateur women's total home-garden MET scores were found to be higher than amateur men. The reason for this is that women are generally thought to be quite active in home-garden activities during the pandemic $(4,9,10)$.

Genç et al. In 2011, they examined the physical activity levels of medical faculty students. As a result of the research, no significant difference was found between the total MET scores of men and women. When we examined our study, no significant difference was found between the work total MET score, transportation total MET score and leisure total MET score of amateur women, amateur men and professional men $(5,11,12)$.

Alricson et al. In a study conducted by Swedish students in 2006, it was stated that men perform more intense activities than women. In our study, however, no significant difference was found in high-intensity activity comparisons between amateur women, amateur men and professional men. The reason for this is thought to be due to the fact that the competitions are not played during the covid-19 pandemic period and the sports fields are closed $(6,13)$.

Dauty et al. In 2020, he conducted a study called the effect of the covid-19 restriction period on the physical conditions of young elite football players. 25 young elite football players were included in the study. Participants performed cardio training 2 days a week and strength training 2 days a week. The trainings were carried out through distance education. In the study, when the pre- and post-pandemic measurements were examined, it was observed that there was a decrease in the aerobic capacity of the participants in their post-tests. The reason for this is thought to be the effect of the covid19 epidemic. In our study, however, no significant difference was found between the MET scores of the participants. Dauty et al. It is thought that the low level of physical activity in our study is due to the covid-19 pandemic period $(7,8)$.

As a result, when we look at the data we obtained from our study, it can be said that the physical activity levels of amateur female, amateur male and professional male football players were low during the covid-19 pandemic period.

\section{Acknowledgement}

This article was created from a master's thesis. 


\title{
Conflict of Interest Statement
}

There are no potential conflicts of interest on this article.

\begin{abstract}
About the Authors
Mustafa Burak Cağdanlıoğlu has a Master of Science degree in the sport science field.

Dr. Mürsel Biçer is Professor Doctor at Gaziantep University, Turkey.

Mehmet Vural is a research assistant at Gaziantep University, Turkey.
\end{abstract}

\section{References}

1. Schiff, M. A. (2007). Soccer injuries in female youth players. Journal of Adolescent Health, 40, 369-371.

2. Bangsbo, J., Mohr, M., and Krustrup, P. (2006). Physical and metabolic demands of training and match-play in the elite football player. Journal of Sports Science, 24(7), 665-674.

3. Özkan, A., Kayıhan, G., Köklü, Y., Ergun, N., Koz, M., Ersöz G., et al. (2012). The Relationship Between Body Composition, Anaerobic Performance and Sprint Ability of Amputee Soccer Players, Journal of Human Kinetics, 35, 141-146.

4. Süsler, A., Üniversite öğrencilerinin fiziksel aktivite düzeyleri ile aşırı besin tüketim isteğinin araştırılması. Düzce Üniversitesi Sağlık Bilimleri Enstitüsü Beden Eğitimi ve Spor Anabilim Dalı Yüksek Lisans Tezi Düzce 2019.

5. Genç A, Şener Ü, Karabacak H, Üçok K. Kadın ve erkek genç erişkinler arasında fiziksel aktivite ve yaşam kalitesi farklılıklarının araştırılması. Afyon Kocatepe Üniversitesi Tıp Fakültesi Fizyoloji A.D, Afyonkarahisar 2011; 12: 145-150.

6. Alricsson M, Landstad BJ, Romild U, 2006. Self-related health, physical activity and complaints in Swedish high school students. Scientific World Journal. 6:816826

7. Dauty, M., Menu, P., \& Fouasson-Chailloux, A. (2020). Effects of the COVID-19 confinement period on physical conditions in young elite soccer players. The Journal of sports medicine and physical fitness.

8. Chen, P. J., Mao, L. J., Nassis, G. P., Harmer, P., \& AinsworthBE, L. F. (2020). Coronavirus disease (COVID-19): the need to maintain regular physical activity while taking precautions. J Sport Health Sci 9: 103-104.

9. Aydın G, Solmaz DY. Spor Bilimleri Fakültesinde öğrenim gören öğrencilerin fiziksel aktivite düzeyleri. İnönü Üniversitesi, Beden Eğitimi ve Spor Bilimleri Dergisi, 2016, 3 (1), ss. 34 - 46.

10. Kitiş Y, Gümüş Y. 20 yaş ve üzeri kadınların fiziksel aktivite düzeyleri, fiziksel aktiviteye ilişkin inançları ve davranış aşamalarının belirlenmesi. Gümüşhane Üniversitesi Sağlık Bilimleri Dergisi / Gümüşhane University Journal of Health Sciences: 2015; 4 (3). 
11. Savcı S, Öztürk M, Arıkan H, İnce Dİ, Tokgözoğlu L. Üniversite öğrencilerinin fiziksel aktivite düzeyleri, Türk Kardiyol Dern Arş - Arch Turk Soc Cardiol 2006; 34 (3) : 166 - 172.

12. Hallal P, BoAndersen L, Bull F, Guthold R, Haskell W, Ekelun U. For the lancet physical activity series working groupt . Global physical activity levels: Surveillance progress, Pitfalls, and Prospects. Volume 380, Issue 9838, 21 - 27 July 2012, Pages 247- 257.

13. Ersöz G, Altındağ E, Abbak Ö, Albayrak Y. Temperament and character traits of university students with regard to physical activity level. Aralık 2016, Cilt: 54 Sayı, 4, s2- 6. 5p.

14. Guerrero-Calderón, B. The Effect of Short-Term and Long-Term Coronavirus Quarantine on Physical Performance and Injury Incidence in High-Level Soccer. Soccer Soc. 2020, 22, 85-95.

15. Bangsbo, J. (1994). The physiology of soccer-with special reference to intense intermittent exercise. Acta Physiologica Scandinavica, 619, 1-155.

16. Wragg, C. B., Maxwell, N. S., and Doust, J. H. (2000). Evaluation of the reliability and validity of a soccer-specific field test of repeated sprint ability. European Journal of Applied Physiology, 83(1), 77-83.

17. Strudwick, T. (2012/14-16 May). Contemporary issues in physical preparation of elite male soccer players. III. World Conference on Science and Soccer Abstract Book, Ghent, Belgium, 113. 
Mustafa Burak Cağdanlioğlu, Mürsel Biçer, Mehmet Vural

INVESTIGATION OF PHYSICAL ACTIVITY LEVEL IN COVID-19 PANDEMIC

PERIOD OF AMATEUR AND PROFESSIONAL SOCCER PLAYERS

Creative Commons licensing terms

Authors will retain the copyright of their published articles agreeing that a Creative Commons Attribution 4.0 International License (CC BY 4.0) terms will be applied to their work. Under the terms of this license, no permission is required from the author(s) or publisher for members of the community to copy, distribute, transmit or adapt the article content, providing a proper, prominent and unambiguous attribution to the authors in a manner that makes clear that the materials are being reused under permission of a Creative Commons License. Views, opinions and conclusions expressed in this research article are views, opinions and conclusions of the author(s). Open Access Publishing Group and European Journal of Physical Education and Sport Science shall not be responsible or answerable for any loss, damage or liability caused in relation to/arising out of conflict of interests, copyright violations and inappropriate or inaccurate use of any kind content related or integrated on the research work. All the published works are meeting the Open Access Publishing requirements and can be freely accessed, shared, modified, distributed and used in educational, commercial and non-commercial purposes under a Creative Commons attribution 4.0 International License (CC BY 4.0). 